\title{
Halkla İlişkilerde Şeffaf İç İletişim ve Dönüşümcü Liderliğin Kurumsal Değişim ve Kurumsal Güven İnşasındaki Rolü
}

\author{
Gonca Yıldırım (Dr. Öğr. Üyesi) \\ İstanbul Aydın Üniversitesi Iletişim Fakültesi \\ goncayildirim@aydin.edu.tr
}

Başvuru Tarihi: 21.09.2020

Yayına Kabul Tarihi: 27.10.2020

Yayınlanma Tarihi: 29.01.2021

https://doi.org/10.17680/erciyesiletisim.797439

\section{Öz}

Özellikle değişim, kriz gibi durumlarda halkla ilişkiler ve iletişimin rolü yadsınamaz bir gerçektir. Ancak buna karşın kurumsal değișim esnasında halkla ilișkiler ve iletişim yaklaşımının gerekliliği birçok kurum tarafından da göz ardı edilmektedir. Bu durumdan yola çıkıldığında; çoğunlukla işletme, yönetim-organizasyon alanında ele alınan değişim yönetimi ve dönüşümcü liderlik bu çalışmada halkla ilişkiler ve şeffaf iletişim açısından ele alınmaktadır. Ayrıca dönüşümcü liderlik ve şeffaf iletişimin, kurumsal değişimin yönetilmesinde ve kurumsal güvenin sağlanmasındaki rolü de bu çalışma kapsamında ilk kez birlikte incelenmektedir. Bu araştırmanın amacı şeffaf iletişim ile kurumsal değişim yönetimi ve kurumsal güven oluşturma arasındaki ilişkiyi ortaya koymaktır. Dönüşümcü liderler ile çalışanların kurumsal değişime açıklığı ve kurumsal güven yaratma arasındaki ilişkiyi test etmek de çalışmanın bir diğer amacıdır. Çalışmanın araştırma kısmı basit tesadüfi örnekleme yöntemi ile ulaşılan 423 kişi ile yapılan anketin verilerine dayanmaktadır. Bulgular, şeffaf iletişimin ve dönüşümcü liderliğin ve çalışanların kurumsal güveni ile olumlu bir şekilde iliş̧kili olduğunu ve bunun da çalışanın değişime açıklığını olumlu yönde etkilediğini göstermiştir.

Anahtar Kelimeler: Halkla İlişkiler, Şeffaf İletişim, Dönüşümcü Liderlik, Kurumsal Değişim, Kurumsal Güven. 


\title{
The Role of Transparent Internal Communication and Transformational Leadership in Public Relations in Corporate Change and Corporate Trust Building
}

\author{
Gonca Yıldırım (Asst. Prof. Dr.) \\ İstanbul Aydın University Faculty of Communication \\ goncayildirim@aydin.edu.tr \\ Date Received: 21.09.2020 \\ Date Accepted: 27.10.2020 \\ Date Published: 29.01.2021 \\ https://doi.org/10.17680/erciyesiletisim.797439
}

\begin{abstract}
The role of public relations and communication is an undeniable reality - especially under the condition of change and crisis. However, after all, the necessity of the approaches of public relations and communication during the institutional change is ignored by various institutions. In this sense, change management and transformational leadership mostly discussed under the sphere of business and management-organization will be discussed in terms of public relations and transparent communication in this study. The role of transformational leadership and transparent communication in the management of institutional change and providing institutional trust, collectively examined for the first time within the scope of this study. The purpose of this research is to introduce the relationship between creating institutional trust and management of institutional change and transparent communication. Another purpose of the study is to test the relationship between transformational leaders and employees' openness to corporate change and creating corporate trust. The research base of the study is based on survey data among 423 people were obtained through the simple random sample method. Results indicate that transparent communication and transformational leadership is related to the institutional trust of employees positively so that this affected positively the openness of employee for the change.
\end{abstract}

Keywords: Public Relations, Transparent Communication, Transformational Leadership, Corporate Change, Corporate Trust. 


\section{Giriş}

Kurumsal değişim, kurumda çeşitli uygulama, süreç veya politikaların kısmen veya tamamen değiștirilmesi amacıyla yapılan çalışmalar dizinidir. Değişim ani-planlı, reaktifproaktif veya mikro-makro boyutlarda gerçekleşebilir. Ancak hangi boyutta olursa olsun değişim, doğası gereği her süreçte bir tedirginlik ve belirsizlik ortamı yaratmaktadır. Uzun ya da kısa bu zaman diliminde kurumun içinde bulunduğu bu olumsuz psikolojik atmosferi yönetmek, çalışanlar arasında güven telkin etmek, kurumu ve bireyleri değişime teşvik etmek konusunda kurum liderleri ayrı bir emek ve çaba göstermek durumundadırlar. Burada katılımcl, vizyoner, motivasyonel vb. özelliklere sahip dönüşümcü liderlerin yanı sıra, stratejik halkla ilişkiler ve şeffaf iletişime de bu zorlu yolculuğu en verimli şekilde aşmak konusunda önemli görevler düşmektedir.

AMA (American Management Association)'ın da belirttiği üzere iletişim yoksa liderlik de olmaz. İyi yönlendirebilmek için iyi iletişim kurmak gerekir. 21. yüzyılda kurumlarına değişim anlamında yardımcı olmak isteyen yöneticilerin, geçen yüzyıldaki meslektaşlarından tamamen farklı bir beceri setine ihtiyaçları vardır. Bu bilgi çağında başarı için emir, zorlama ve tehditleri unutup, çalışanların katılımını ve yaratıcı işbirliğini sağlamak esastır. Değişimin başarısı lidere, etkin yönetime, erken, kapsamlı ve şeffaf iletişime bağlıdır (2019).

Karizma ve vizyon sahibi yöneticiler olarak dönüșümcü liderler, sadece değișimin yürütülmesi değil aynı zamanda çalışanların motivasyonu artırmak, kuruma karşı bağlılık ve güven oluşturmakla da yükümlüdürler. Yapılan çeșitli araștırmalar dönüșümcü liderlik uygulamalarının çalışanlar üzerinde olumlu sonuçlar yarattığını ortaya koymaktadır (Pawar \& Eastman, 1997; Eisenbach, Watson, \& Pillai, 1999; Wong \& Cummings, 2009; Bass \& Avolio, 2004; Al-Qura'an, 2016). Benzer şekilde kurumsal değişim sürecinde kurumsal iletişimin önemini tartışan çeșitli çalışmalar da mevcuttur (Johansson \& Heide, 2008; Men \& Yue, 2019; Pitt, Murgolo-Poore, \& Dix, 2001; Rawlins, 2008; Verčič \& Vokić, 2017).

Ancak Türkiye'de konuyla ilgili birçok çalışma genellikle işletme ve organizasyon bazlı ele alınırken özellikle halkla ilişkiler perspektifinin kullanılmadığı gözlenmektedir. $\mathrm{Bu}$ durumun dünya genelinde olduğunu savunan Yue, Men ve Ferguson (2019) da bu eksiklikten yola çıkarak halkla ilişkiler, şeffaf iletişim ve dönüşümcü liderlik ekseninde değişimi ele almışlardır. Bu araștırma da hem Yue, Men ve Ferguson'un çalışmalarından hem de Türkiye'de bu kapsamda bir araştırma olmamasından yola çıkılarak hazırlanmıştır. Halkla ilişkiler ve șeffaf iletişim perspektifiyle değişim yönetimi, dönüşümcü liderlik ve çalışan güveninin birlikte ele alınması bu çalışmayı işletme bazlı diğer çalışmalardan farklılaştırmaktadır. Bu çalışmada kurumsal değişim sürecinde stratejik halkla ilişkiler bakış açısıyla şeffaf iletişimin ve dönüşümcü liderlerin iletişim rolleri incelenmektedir. Ayrıca değişim sırasında şeffaf iletişim ile çalışanların değișime açık olması arasında nasıl bir ilişki olduğu da irdelenen bir diğer konudur. Kısaca bu çalışma kurumsal değişim sırasında dönüșümcü liderler ve șeffaf iletişimin çalışanların değişime açıklı̆̆ı ve kurumsal güveni üzerindeki ilişkiyi incelemektedir.

\section{Halkla ilişkiler ve Şeffaf İç iletişim}

Bir iletişim yönetimi olarak halkla ilişkiler kurum içi ve kurum dışı iletişim faaliyetlerini kurmak ve yönetmekle sorumludur. Günümüz halkla ilişkileri, iki yönlü simetrik ve mükemmel halkla ilişkiler modelleri ile daha sıkça fikir alışverişi, karşılıklılık, açıklık, 
şeffaflık ve dengeli değişim çerçevesinde bireylerin iletişim ihtiyaç ve sorunlarına cevap verme şansına sahiptir.

Grunig'e göre simetrik iletişim modeli, karşılıklı olarak uyum çerçevesinde kurumlar ve paydaşlar arasında çözüm amaçlı diyalogu savunmaktadır. İç iletişim bağlamında,. Üst düzey liderler de iç iletişimin tonunu belirler ve bir kurumun itibarını şekillendirir. Liderler işle ilgili bilgilerin en güvenilir kaynağı olarak simetrik iletişim modeli "güven, güvenilirlik, açıklık, ilişkiler, karşılıklılık, ağ simetrisi, yatay iletişim, geri bildirim, bilgi yeterliliği, çalışan merkezli stil, anlaşmazlık toleransı ve müzakere" üzerinde durur. Grunig'e göre bir örgütün iç iletişim sistemi, hem mükemmel halkla ilişkilerin gerekli şartını hem de mükemmel halkla ilişkiler programlarının bir parçasını oluşturur. İç iletişim, halkla ilişkilerde mükemmelliği sağlayan koşullarla ayrılmaz bir ilişki içindedir (Grunig, 2005, s. 557-558). İç iletişim sistemi temel olarak üç bileşenden oluşur: kurumsal iç iletişim, liderlik ve yatay iletişim. Kurumsal iç iletişimi genellikle iletişim departmanı yönetir görülmektedir (Men \& Bowen, 2017).

Etkili liderlik, iletişim olmadan en üst düzeyde çalışamaz. İletişim şeffaflığı "doğru, önemli ve yararlı" bilginin açıklanmasını gerektirir. İletişimde katılımcı şeffaflık, çalışanların bilgi ihtiyaçlarını karşılamak için ilgili bilgileri belirlemeye yönelik örgütsel bir çabadır. Bir kuruluş, çalışanlara danışmadan ve geri bildirimlerini sormadan, çalışanların istediği ve bilmesi gereken önemli ve ilgili bilgileri sağlayamaz. Hesap verebilir şeffaflık ise hem olumlu hem de olumsuz bilgilerin iletişime dahil edilmesiyle ilgilidir (Rawlins, 2008).

Kurulan sağlıklı iç iletişim süreci, çalışanların gözünden kurumun itibarı ve saygınlığının inşa edilmesi noktasında da önem arz etmektedir. İç iletişim ile yönetimin kurumsal itibarı oluşturmasını (Seitel, 2016, s. 245) çalışanları dinlemek, değişen teknolojilerle çalışanları eğitmek için bilgi alışverişini geliştirmek, yeni bilgi ve becerilerle çalışanları yetkilendirmek, durağanlığın yerini hareketliliğin aldığı yeni iş kültürüne uyum sağlamak gibi farklı faktörlere bağlı olduğunu belirtmektedir.

Değişim sırasında kurumsal iletişim ve liderliğin ve çalışanların değişime karşı tepkilerini inceleyen ilk ampirik çalışmalardan biri olarak önemli bulgular ortaya koyan Yue, Men ve Ferguson (2019)'un çalışmasına göre bilginin, katılımcılığın ve hesap verebilirliğinin önemli olduğu şeffaf iletișimin çalışanların değișimler karşısındaki tutumları üzerinde büyük etkisi bulunmaktadır. İç halkla ilişkiler perspektifinden kurumsal değişime bakan söz konusu çalışma; iç iletişimin değişim sırasındaki güven ve değişime açıklık üzerindeki etkisini ortaya koymaktadır. Çalışmaya göre şeffaf iletişim, değişim uygulamasını kolaylaştırmada önemli bir role sahip bulunmaktadır. İletişim ve değişimi birbirinden ayrılmaz bir bütün olarak ele alan Pitt, Murgolo-Poore ve Dix (2001) de etkili iletişimin, değişim yönetimi uygulamalarının başarısında anahtar rol oynadığını vurgulamaktadırlar. Men ve Yue, (2019) ABD'de çalışanlar üzerinde yaptıkları araştırmada simetrik iletişim ve duyarlı liderlik iletişiminin örgütlerde olumlu bir duygusal kültürü geliştirdiğini, değişimi kolaylaştırdığını bulmuşlardır. Verčič ve Vokić (2017) de iç iletişim ve çalışan bağlılığının sürekli bir sanal çevrede birbirini beslediğini görmüşlerdir. Ayrıca, Rawlins, (2008) şeffaf iç iletişim ile çalışanların kuruluşlara olan güveni arasında doğrudan pozitif bir ilişki bulmuş, şeffaf iletişim sayesinde çalışanların güveninin geliştirebileceğini savunmuştur. Johansson ve Heide (2008) ise kurumsal değişimde iletişimin önemli rolü olmasına rağmen, kurumsal değişime halkla ilişkiler perspektifi ve iletişim yaklaşımının eksikliğine dikkat çekmektedir. 
Bütün iş süreçleri ve iş akışı kurumsal iletişim örüntüsüne göre düzenlenmektedir diyebiliriz. Çünkü bir kurumda işlerin başlangıcından bitiş noktasına kadar olan süreçte dikey, yatay ve çapraz iletişim örüntüsünün sağlıklı işlemesi önemli bir olaydır. Bütün bu süreç ve akış içinde çalışanların kurumlarına olan güven ve bağlılıkları ile işin kaliteli, zamanında, verimli ve etkin bir şekilde yapılması arasında doğrudan bir ilişki vardır.

İç iletişim sistemleri örgütün yapı ve kültürünün bir parçasıdır ama bu sistemler aynı zamanda yapıyı ve kültürü yaratır. Örgüt ortamı, örgütteki güç sahibi bireylerin örgütün yapı, kültür ve iletişimini biçimlendirişi üzerinde etkili olur. Ama diğer yandan yapı, kültür ve iletişim de örgütte kimin güç sahibi olacağı üzerinde ve bir örgütün kendi ortamını algılama ve ona tepki gösterme biçimi üzerinde etkili olur (Grunig, 2005, s. 558). İç iletişim sistemleri Grunig'in de vurguladığı üzere kurumsal kültürü, yapıyı ve güç sahibi bireyleri yani liderleri şekillendirir. Bu etkileşim karşılıklı bir döngü şeklinde devam eder. Liderlerin mükemmel ve simetrik halkla ilişkiler çerçevesinde şeffaf iletişim sürecini inşa etmeleri, astları ile bu boyutta iletişim kurmaları, çalışanların gerek kurumlarına gerekse liderlerine güven duymaları noktasında önem arz etmektedir.

\section{Dönüşümcü Liderlik ve Değişim}

Liderlik, kurum çalışanlarını etkileyerek, amaç ve hedeflerin gerçekleștirilebilmesi yolunda onları yönlendirmek ve yönetmektir. Lider ise başkalarını belli bir amaç doğrultusunda davranmaya sevk eden, etkileyen kișidir (Erdoğan \& Hepkul, 2017, s. 126). Liderlik, bir sosyal etki süreci olarak tanımlanabilir (Parry, 1998).

Bass (1985), liderlerin vizyon yaratarak değişimi teşvik etmeleri gerektiğini önermektedir. Van Knippenberg ve van Leeuwen (2001)'e göre liderlik, insanları ortak amaçlar için mücadele etme yolunda harekete geçirme sanatıdır. Bu nedenle liderlerin, değişim yöneticileri olarak başarılı bir şekilde hareket etmeleri, diğerlerini kendilerini takip etmeye motive edebilmeleri ve değişim yönetimi süreçlerinde yetenekli olmaları gerekir. Brown ve Eisenhardt (1997), sürekli değișen kurumlarda başarılı yöneticilerin üç temel özelliğini şöyle sıralamaktadırlar: Başarılı yöneticiler, kapsamlı iletişim ve anlık durum yönetim becerileriyle sorumluluk ve önceliklerini yerine getirir; geleceğe yönelik araştırmalar yapar, öğrenir; mevcut projelerle gelecekte öngörülebilir süreçleri bağlayarak geçmiş-bugün-gelecek arasında bir geçiş süreci oluşturur.

Liderlik alanındaki bazı araştırmalar dönüşümcü liderliğin rutin olmayan durumlar için daha iyi olduğunu, hatta adaptasyon amaç olduğunda kuruluşların dönüşümcü liderle daha başarılı oldukları fikrini desteklemektedir. Dönüşümcü, karizmatik ve vizyoner liderler, dönüşüm sürecindeki uygun aşamada uygun davranışları göstererek kuruluşlarındaki statükoyu başarıyla değiștirebilirler. Eski yolların artık işe yaramadığının farkına varıldığında, bu liderler geleceğe yönelik çekici bir vizyon geliştirme görevini üstlenebilirler. İyi bir vizyon, değişim için hem stratejik hem de motivasyonel bir odak sağlar aynı zamanda bir ilham ve bağlılık kaynağıdır (Eisenbach, Watson, \& Pillai, 1999; Pawar \& Eastman, 1997).

Eisenbach, Watson ve Pillai (1999), yeni bin yılla birlikte kurumsal dönüşüme odaklanan dönüşümcü, karizmatik ve vizyoner liderlik gibi liderlik modellerinin, iş dünyası ve siyasi ortamda öngörülen nefes kesen değişiklikler karşısında kuruluşlar için çok daha önemli hale geleceğini öngörmüşlerdir. Koçel (2011, s. 592)'e göre dönüşümcü lider, kurumları değişime ve yenilenmeye hazırlayıp bunu gerçekleştiren ve üst düzey performansa ulaştıran kişidir. Drucker (2000, s. 85) hızlı bir değişim döneminden 
geçen kurumların hayatlarının devamlılığını, bu kurumların değişim liderlerine sahip olmalarına bağlamaktadır. Bass ve Avolio (2004), dönüşümcü lideri, astların tüm bilgi birikimini ve becerilerini ortaya çıkaran, motivasyonunu yükseltmeye çalışan, reformcu, değişimci, yenilikçi, çalışanların değer yargılarını ve inançlarını değiştirebilen kişiler olarak tanımlamaktadır. Aksaraylı (2015) da dönüştürücü liderliğin, içinde bulunduğumuz sürekli değişim çağında, kurumlarda değişimi yönetecek, kurumu ve iş görenleri değişime adapte edebilecek ve kurumun varlığını sürdürebilecek liderlik tipini temsil ettiğini belirtmektedir. Kouzes ve Posner (akt. Wong \& Cummings, 2009) dönüşümcü liderliği; sürece meydan okuma, ortak bir vizyona ilham verme, başkalarının harekete geçmesini sağlama, yolu modelleme ve teşvik etme gibi beş temel davranışla kavramsallaştırırlar. Dönüşümsel liderliğin idealleștirilmiş etki, ideal davranışlar, ilham verici motivasyon, entelektüel uyarım ve bireysel destek şeklinde beş alt boyutunu tanımlayan Bass (1995, s. 468) yaptığı çalışmada, üst düzey dönüşümcü liderlerin ekstra çaba, yaratıcılık ve üretkenlik yaratmak için takipçilerin beklentilerini aşacak şekilde hareket ettirebilecekleri sonucuna varmıștır.

Literatürde sıklıkla ele alınan, kurumsal anlamda geliştiren ve kavramsallaştıran Burns (1978), Bass (1985), Nadler (1983), House, Spangler ve Woycke (1991) gibi yazarlar dışında dönüşümcü liderlerin kişilik, karizma, vizyon, motivasyon vb. güçlerinin incelendiği çok sayıda yeni araştırma eklenmiştir. Pawar ve Eastman (1997) araştırmalarında değişimi, dönüşümcü liderliği etkileyen bağlamsal bir değişken olarak entegre etmeye çalışmışlardır. Saylı ve Tüfekçi (2008) çalışmalarında dönüştürücü liderlerin, örgütsel değişimi başlatma, sürdürme ve dondurma noktasında pozitif etkileri olduğunu bulmuşlardır. Herold, Fedor ve Caldwell (2007) dönüşümcü liderliğin, iyi değişim yönetimi uygulamalarının yanı sıra, değişime bağlılık ile de ilişkili olduğunu bulmuşlardır. Al-Qura'an (2016) bankacılık sektöründe yaptığı bir araştırmada dönüşümcü liderlik boyutlarının (idealize edilmiş etki, ilham verici motivasyon, entelektüel uyarım, bireyselleştirilmiş düşünce ve yetkilendirme) örgütsel değişim yönetimini yapısal, teknolojik ve insan düzeyinde etkilediğini göstermiștir.

Dönüşümcü liderler, takipçilerin amaçlara ulaşma konusunda güven duymalarını sağlar, takipçiler için rol model olur, takipçilerin kendilerini adama düzeylerini yükseltir (Koçel, 2011). Buradan yola çıkarak dönüşümcü liderliğin yenilikçi, vizyoner, karizmatik ve etkileşimci yapısının, çalışanların kurum iklimine, kültürüne adaptasyonunu hızlandırmakla birlikte, çalışanların geleceğe dönük değişim programlarına da ayak uydurmalarında önemli rol oynadıklarını söyleyebiliriz.

\section{Kurumsal Değişim Yönetimi}

Değişim, var olan bir durumun, konumun yakın veya uzak bir gelecekte farklılaşmasıdır. Artan rekabet koşulları, sürekli gelişen bilgi teknolojileri, her an ortaya çıkabilecek kriz ortamları, çevresel-doğal faktörlerin zorlamaları, ekonomik ve siyasi sebepler, pazarın ve sektörün gereklilikleri gibi nedenler kurumları sürekli bir değişim çabası içine itmektedir. Yöneticiler, müşteriler, çalışanlar, hissedarlar gibi sosyal paydaşlar da kurumu değişime zorlamaktadır. Değişimi yönetebilen kurumlar sürekliliklerini sağlarken, ayak uyduramayanlar ise bir süre sonra yerlerini bırakmak zorunda kalmaktadırlar. Çünkü değişime karşı direnç gösteren bazı kurumlar bir süre sonra toplumun, çalışanların talep ve beklentilerini karşılayamayacakları için devre dışı kalmaktadırlar. Bu postmodern çağda, kurumlar hem düzeni sağlamak hem de değişim başlatıp sürdürebilmek gibi dinamik bir kaosla uğraşmak zorundadır. 
Bouckenooghe, Devos ve Van Den Broeck (2009) etkili değişim yönetimini değişim iletişiminin kalitesi, katılım, üst yönetimin örgütsel değişime karşı tutumu ve denetçilerin desteğinin bir fonksiyonu olarak tanımlamışlardır. Kurumsal değişimin devrimci ve/ veya evrimsel bir süreç olduğunu savunan Alvesson ve Sveningsson (2016), devrimci değişim sürecini kurumsal iklim, teknolojik altyapı, kurumsal yapı, liderlik biçimleri, insan kaynakları yönetimi gibi büyük ölçekli değişiklikler olarak tanırlarken; evrimsel değișiklikleri ürün tasarımındaki değişiklikler, mevcut sürecin, stratejinin iyileştirilmesi gibi bölüm bazlı daha dar kapsamlı ve operasyonel değişiklikler olarak ele almaktadırlar. Koçel (2011) kurumları değişime zorlayan faktörleri kurum içi faktörler (ürün/ hizmetlerin performansı, çalışanların talep ve beklentileri, çalışma koşulları, yönetim kadrosu vb.) ve kurum dişı faktörler (küreselleşme, artan rekabet, siyasi, ekonomik, sosyo-kültürel koşullar, teknolojik gelişmeler vb.) şeklinde iki şekilde ele almaktadır. Miller (1998)'a göre de kurumları değişime zorlayan üç temel sorun vardır. Bunlar rekabetçi pazar yapısından kaynaklanan sorunlar, toplumsal-sosyal çevreden kaynaklar sorunlar ve iş gücünden kaynaklanan sorunlardır.

Bir kuruluşta değişiklik yapılması zorunlu olabilir veya bir kuruluş çevreye veya iç gereksinime yanıt olarak değişebilir. Değişim güçleri birbirine bağımlıdır ve kurumları birçok yönden etkiler. Son yıllarda değişim baskısının en güçlü göründüğü alanlar özellikle teknoloji, bilgi ve iletişim, rekabet ve sosyal eğilimler olduğu söylenebilir (Moorehead \& Griffin , 2010). Beck, Brüderl ve Woywode (2008)'in belirttiği üzere değișim girişimleri arasında yeni teknolojilerin tanıtılması, birleşme ve satın almalar, örgütsel yeniden yapılandırma, örgütsel liderlik değişiklikleri, küçülme ve işten çıkarmalar gibi çok çeşitli konular bulunmaktadır.

Her değişimin bir gelişme olmadığını belirten Selvi (2007), değișmeler sürdüğü sürece işletmelerin sorunlara çözüm getirmek için yeni arayışlarda bulunacaklarını ve bu sebeple gelişmelerin devam edeceğini söylemektedir. Değişimin olumlu ya da olumsuz olabileceğini ifade eden Selvi'ye göre, olumlu değișme yöntem ve süreçleri daha etkin hale getirirken, olumsuz değişme dağılmayı ve etkinliğin azalmasını tetikleyebilir. Her türlü değişim ve gelişmeye açık kurumlar aynı zamanda öğrenen kurumlardır. Bu "açık olma" durumu da başarılı değişim ve gelişimin anahtarıdır. Baykal (2019) da çalışmasında planlı değişim süreçlerinde, üst yönetim desteğinin ve çalışan desteğinin sağlanmasının, detaylı değişim planının yapılmasının ve tüm paydaşları teşvik eden bir değişim vizyonunun oluşturulmasının değișim sürecini kolaylaştıran faktörler olduğunu ortaya koymaktadır. Manning (2012) de değişim yönetiminde başarının temel unsurlarını stratejik düşünme, liderlik, görev yönetimi, ilişkiler ve kaynaklar olarak sıralamaktadır.

Kurumlar bazı dönemlerde değişime hazırken bazı dönemlerde değişime pek yatkın değildir. Özellikle değişimin getireceği fayda, zararından daha fazla olacağı inancı yaygın ise değişme meydana gelir. İçinde bulunulan ortamdaki tatminsizlik oranı, arzulanan bir alternatifin varlığı ve bu alternatifi gerçekleştirebilecek bir planının olması, değişimin gerçekleşmesinde önemli üç faktör olarak kabul edilmektedir (Özkalp \& Kırel, 2010, s. 442).

\section{Değişime Direnç ve Açıklık}

Kurumsal değişim, kurumun mikro ve makro çevresel faktörlere uyumunu sağlarken; kurumlara daha yüksek verimliliğe ulaşma, etkililik, alanda yetkinlik, yenilikçilik, çalışan motivasyonu, güçlü iş kaynağı gibi çok farklı artı değerler katmaktır. Planlı-plansız, reaktif-proaktif, mikro-makro değișim her ne șekilde olursa olsun bireyleri ve kurumların 
ortamlarını, durumlarını kısmen veya tamamen farklılaştırır. Ancak her değişim süreci, sonucu olumlu ya da olumsuz olsun hem kurumlar hem de bireyler için bir belirsizlik ve tedirginlik dönemidir.

Her kurumdaki değişim süreci, o kurumun doğası, işin yapısı, çalışma kültürü ve değerleri, yönetim ve liderlik tarzı ile çalışanların davranışları ve tutumlarındaki farklılıklar nedeniyle birbirinden farklıdır. Bazıları için değişim memnuniyet, sevinç ve avantajlar getirirken, diğerleri için aynı değişiklik acl, stres ve dezavantajlar getirebilir (Abdul Rashid, Sambasivan, \& Abdul Rahman, 2004). Paradoksal olarak kurumlar hem değişimi destekler hem de direnç gösterirler. Değişmeye direnç doğrudan veya dolaylı olabilir. Doğrudan dirençte örneğin değişiklik önerilip uygulanmaya konulduğunda çalışanların şikayetleri artar, işi yavaşlatma hatta grev ve direnişler ortaya çıkabilir. Ya da kuruma olan bağlılığın azalması, güdülenme kaybı, hataların artması gibi anlaşılması güç dolaylı direnç çabaları ortaya çıkar. Değişmeye direnç bireysel, kurumsal veya her ikisinden kaynaklı olabilir (Özkalp \& Kirel , 2010, s. 445).

Çalışanlar, alışagelmiş düzen ve sistemin değişmesi durumunda tepkiler gösterir, ilk etapta eskiyi devam etmeye çalışırlar. Çalışanlar için eğer değişim; iş güvenini, alışkanlıklarını ve güvenlik duygusunu tehdit ediyorsa, gelirinin azalması ile karşı karşıya ise, çalışacağı ortamı ve yöneticiyi tanımıyorsa, kullanması gereken teknolojiyi bilmiyorsa kabul edilmesi güç bir olaydır. Öte yandan değişime sadece çalışanlar değil kurumlar da direnç gösterirler. Değişim, yönetimin politikaları ile çelişiyorsa, ek bir maliyet getiriyor ve bunu karşılayacak güçte değilse, katı-kararlı içyapı sistemlerine sahipse, kaynakların kesilmesi söz konusu ise değişimi yönetecek bir kadroya sahip değilse, yöneticilerin gücünü tehdit ediyorsa kurum kaynaklı direnç ortaya çıkabilir (Moorehead \& Griffin, 2010; Nadler, 1983; Robbins , Millett, \& Waters-Marsh, 2008).

Augustsson, Richter, Hasson ve von Thiele Schwarz (2017) araştırmalarında çalışanların değişime niyetli ve psikolojik olarak hazırlıklı olma durumlarında değişimin çıktılarının daha olumlu olduğunu ortaya koyarken; Appelbaum, Degbe, MacDonald ve NguyenQuang (2015) liderliğin birden çok düzeyde girdiyle hareket ettiğini ve örgütsel sonuçları doğrudan etkilediğini, çalışanların değișim boyunca sürekli olarak tutumlarını şekillendirdiklerini tespit etmişlerdir. Moorehead ve Griffin (2010) değişime direnci kırma yöntemlerini; üst yönetimin destek vermesi, tartışma ve uzlaşma ortamlarının yaratılması, çalışanların katılımcılığının desteklenmesi, açık bir iletişim yürütülmesi, değişim çabalarına katkıda bulunanların ödüllendirilmesi, eğitim ve yönetim geliştirme programlarının sunulması şeklinde önermektedirler.

Dönüşümcü liderler, oluşturdukları belli bir vizyon çerçevesinde, katılım stratejilerini de kullanarak, ortak bir hedefe yönelik çalışma konusunda çalışanlarını motive etmede başarılı olabilirler. Ayrıca karşılıklı yapılan kişisel fedakarlıklar da kolektif çıkarlara bağlı kalırlar ki bu da istenen kurumsal değişikliği sağlayabilir (Yukl, 2018).

Eisenbach, Watson ve Pillai'a (1999) göre liderler, paydaşlarını farklı değişim olasılıklarına çekmek için onların temel ihtiyaçlarını ve değerlerini dikkate alan çekici bir vizyon oluşturmalıdır. Bu vizyon geliştirildiğinde ise lider, değişimi uygulamaya koymalıdır. Bu, liderin çalışanlar için zorlu hedefler koyduğu ve eski iş yapma yollarını yeniden düşünmeye motive ettiği bir uyarım yoluyla yapılabilir. Lider, çalışanların başarı ve büyüme ihtiyaçlarına hitap ederek ve değişikliği çekici bulmalarını teşvik ederek değişimi çerçeveler. Değişim süreci dönüşümcü liderin çalışanlarına destek, koçluk ve rehberlik sağladığı durumlarda ise daha bir kolaylaşmaktadır. Dönüşümcü bir liderin 
takım çalışmasını teşvik ederek bir kültürün oluşturulmasını sağlaması da bu sürecin kolaylaştırıcısı olacaktır.

\section{Çalışanlarda Kurumsal Güven ve Değişim}

Bir kurum için alınan herhangi bir karar sadece o kurumu değil çalışanlarını da ilgilendirir. Kararlar özellikle çalışanların hayatlarını ve iş yapış biçimlerini etkiliyorsa, çalışanların da bu kararlara katılımları sağlanmalıdır. Çalıșanlara bir 'insan' oldukları duygusunu aktarmak, bu duyguyu onlarda yaşatmak, iş ortamlarını beklenti ve yeteneklerine uygun hale getirmek, işlerini zenginleştirmek kendilerini güvende hissetmelerini, kendilerine değer verildiğini düşünmelerini ve mutlu çalışan olmalarını sağlayacaktır (Paşa, 2002). Bu noktada dönüşümcü liderlerin ve değişim kadrosunun halkla ilişsiler süreçleri ve fonksiyonları doğrultusunda ortaya koyacakları şeffaf iletişim yöntemleri önemli rol oynayacaktır.

Değişimde en önemli faktör insan olsa da bu süreçte yönetilmesi gereken en zor unsur yine insandır. Bu nedenle, değişim sürecinde kurumdaki insanları yönetmek, onların değerleri, tercihleri ve belirli bir faaliyete yönelik tutumlarını ele almak büyük bir zorluktur (Abdul Rashid, Sambasivan, \& Abdul Rahman, 2004). Dönüşümcü liderlik genellikle karizmatik liderliğe dayanır ve karizmatik liderlik, çalışanlar arasında güven ve güvenilirlik gerektirir (Simons, 1999).

Konuyla ilgili literatür çalışmalarında; Bass (1985) astların güvenini dönüşümcü liderliğin bir sonucu olarak tanımlamış ve güveni, karizmatik liderliğin ayrılmaz bir bileșeni olarak göstermiştir. Kouzes ve Posner (1993) araştırmalarında, liderlerin yapacaklarını söyledikleri şeyi yaptıklarında, vaat ettiklerini uyguladıklarında, eylemleri ile sözlerinin tutarlı olduğunda çalışanların daha çok güvenini kazandıklarını; Bartlett ve Ghoshal (1995, s. 18), değişimin yönetilmesi için güvenin gerekli olduğunu, çünkü risk almak için güvenin gerekli olduğunu ve liderlerin kişisel risk almalarının da örgütsel değişimin ayrılmaz bir parçası olduğunu savunmaktadır. Simons (1999) çalışmasında, dönüşümcü liderlerin davranışsal bütünlüklerini devam ettirmelerinin, değişim sürecinde çalışan güveni ve bağlılığın geliştirilmesi için kritik bir öneme sahip olduğunu göstermektedir. Devos, Buelens ve Bouckenooghe (2007), çalışanlar ve yöneticiler arasındaki güven ilişkisinin, uygun değișim zamanı ve değișim çabalarına katılımın değișim girişimi başarısının temelini oluşturduğunu; Cook, Yamagishi, Cheshire ve Mashima (2005), güven ilişkilerinin inşasında risk almanın önemli olduğunu; Cai, Loon ve Wong (2018) ise yönetime duyulan güvenin, hem liderlik türleri hem de değişimin kabulü ile ilişkili olduğunu ve dönüşümcü liderliğin değișimin güvenini ve kabulünü artırmada daha etkili olduğunu göstermektedirler.

Dönüşümcü liderler; kurumlarının vizyonunda, kararlarında, kültüründe değişim yaratan, öncülük eden liderlerdir. Kurumsal sistem içinde değişimlerin başlatılması ve sürdürülmesi noktasında çalışanlar arasında etkileşimci ortamların yaratılması, çalışanların teşvik edilmesi, motivasyonlarının güçlendirilmesi, kurumsal destek oluşturulması, sorunların ve belirsizliklerin giderilmesinde liderlerin sunduğu güven ortamı kilit derecede önemlidir. Güven olgusu etkileyici liderler yönetiminde ve sağlıklı iletişim iklimi içinde gelişir ve büyür. Yue, Men ve Ferguson'a (2019) göre de çalışanlar kurumlarına güvendiklerinde değişimin iyi niyetine de güvenme olasılıkları yüksek olacaktır. Kurumsal güven atmosferi dönüşümcü liderliğin dönüşümcü liderliğin ve şeffaf iletişimin gücünün ortaya çıktığı kilit bir aracı görevi görmektedir. 


\section{Araştırmanın Amacı ve Önemi}

Çeşitli sebeplerle değişim yaşanması, önüne geçilemez bir gerçekliktir. Önemli olan ise bu değişimin nasıl yürütüldügü ve yönetildiğidir. Hızlı gelişmelerin yaşandığı 21. Yüzyılda değişimlerin yönetiminde, liderlik modelleri arasında özellikle dönüşümcü liderler öne çıkmaktadır. Değişim yönetimi-dönüşümcü liderlik; iletişim-dönüşümcü liderlik; iletişimkurumsal güven gibi farklı paradigmalarla karşımıza çıkan araştırmalar genelde işletme ve yönetim odaklı olurken; halkla ilişkiler ve şeffaf iletişim perspektifinden yaklaşan bu çalışma bu yönüyle diğerlerinden ayrılmaktadır.

$\mathrm{Bu}$ çalışmanın odak sorunsalı, şeffaf iletişimin ve dönüşümcü liderliğin çalışanların güvenini ve değişime açıklığı tetiklemedeki etkilerini değerlendirmektir.

$\mathrm{Bu}$ araştırmanın birincil amacı, şeffaf iletişimin kurumsal değişim sürecinde etkili olup olmadığını ortaya koymaktır. Bu doğrultuda şeffaf iletişim ile çalışanların değişime açıklığı ve kurumsal güven arasındaki ilişkiyi ortaya koyabilme amaçlanmaktadır. $\mathrm{Bu}$ çalışmanın ikinci amacı ise dönüşümcü liderler ile çalışanların kurumsal değişime açıklığı ve kurumsal güven yaratma arasında ilişki olup olmadığını ortaya koymaktır. Genel olarak bu çalışma ile kurumsal değişim sürecinde şeffaf iletişimin ve dönüşümcü liderlerin çalışanların değişime açıklığı ve kurumsal güveni arasındaki ilişki araştırılmaktadır.

Araştırma alanı olarak kurumsal değişimi etkileyen faktörler kapsamında şu alt sorulara yanıt aranmaktadır: Kurumlar değişim sürecinde şeffaf iletişim kapsamında çalışanları için (katılım, önemlilik, hesap verilebilirlik) sorumluluklarını yerine getiriyorlar mı? Kurumsal değişim sürecinde liderler, çalışanlarına dönüşümcü liderliğin gerekliliklerini (ideal etki, entelektüel teşvik, motivasyon, bireysel destek) aktarabiliyorlar mı? Şeffaf iletişim ve dönüşümcü liderlik çalışanların kurumsal güvenini sağlayıp ve değișeme açıklığını destekliyor mu?

\section{Araştırmanın Yöntemi ve Sınırlılıklar}

Araştırmada veri toplama aracı olarak nicel araştırma yöntemlerinden anket kullanılmıştır. Çalışma sadece İstanbul ili sınırları içinde yaşayan, özel kurum ve kamu kurumlarında çalışanlar ile sınırlı tutulmuştur. Araştırma 27.04.2020-27.05.2020 tarihleri arasında gerçekleştirilmiștir. Anket 3 kısımdan oluşmaktadır. Birinci kısımda demografik özellikler, ikinci kısımda şeffaf iletişime dair (katılım, önemlilik, hesap verilebilirlik) 16 soru, üçüncü kısımda dönüşümcü liderliğe dair (ideal etki, entelektüel teşvik, bireysel motivasyon, bireysel destek) 11 soru ve kurumsal güvene dair 6 soru ve değişime açıklık konusunda 4 soru yer almaktadır. Anket 5’li likert ölçeğine göre düzenlenmiştir.

\section{Araştırmanın Evren ve Örneklemi}

Başlangıçta çalışmanın, son bir-iki yıl içinde değişim yaşamış ya da hala değişim süreci içinde olan kurumlar nezdinden yapılması planlamıștı. Ancak Ocak 2020 itibariyle tüm dünyayı etkisi altına alan Covid-19 sonrasında hem kișiselde hem de iş dünyasında köklü bir değişim yaşanması, otomatik olarak tüm işletmeleri bir değişim sürecine sokması böyle bir ayrım yapmaya gerek bırakmamıștır. Çalışmanın evreni Türkiye'de faaliyet gösteren özel-kamu kurumu çalışanları iken örneklemi İstanbul'da faaliyet gösteren kurumlarda çalıșanlar olarak belirlenmiștir. Anketler Google Forms üzerinde hazırlanmış ve e-mail ve WhatsApp üzerinden basit tesadüfi örnekleme yöntemi ile çalışanlara gönderilmiştir. Toplamda 725 kişiye anket formu gönderilmiş ve geri dönenen 423 anket değerlendirmeye alınmıștır. 


\section{Araştırmada Kullanılan Ölçekler ve Araştırmanın Modeli}

Araştırmada Yue, Men ve Ferguson'un (2019), "Bridging transformational leadership, transparent communication, and employee openness to change: The mediating role of trust" adlı makalelerinde kullandıkları ölçek Türkçeye ve Türkiye'ye uyarlanmıştır. Etik olarak ölçek kullanımı için öncesinde Yue ve arkadaşlarından izin alınmıştır. Türkçe çevirisi yapıldıktan sonra Üniversitede İngilizce programlarında eğitim veren iki Dr. Öğr. Üyesi ve Uygulamalı İngilizce Çevirmenlik bölümünde görevli bir Dr. Öğr. Üyesi tarafından kontroller yapılmış ortak anlaşma ile ankete son şekli verilmiștir.

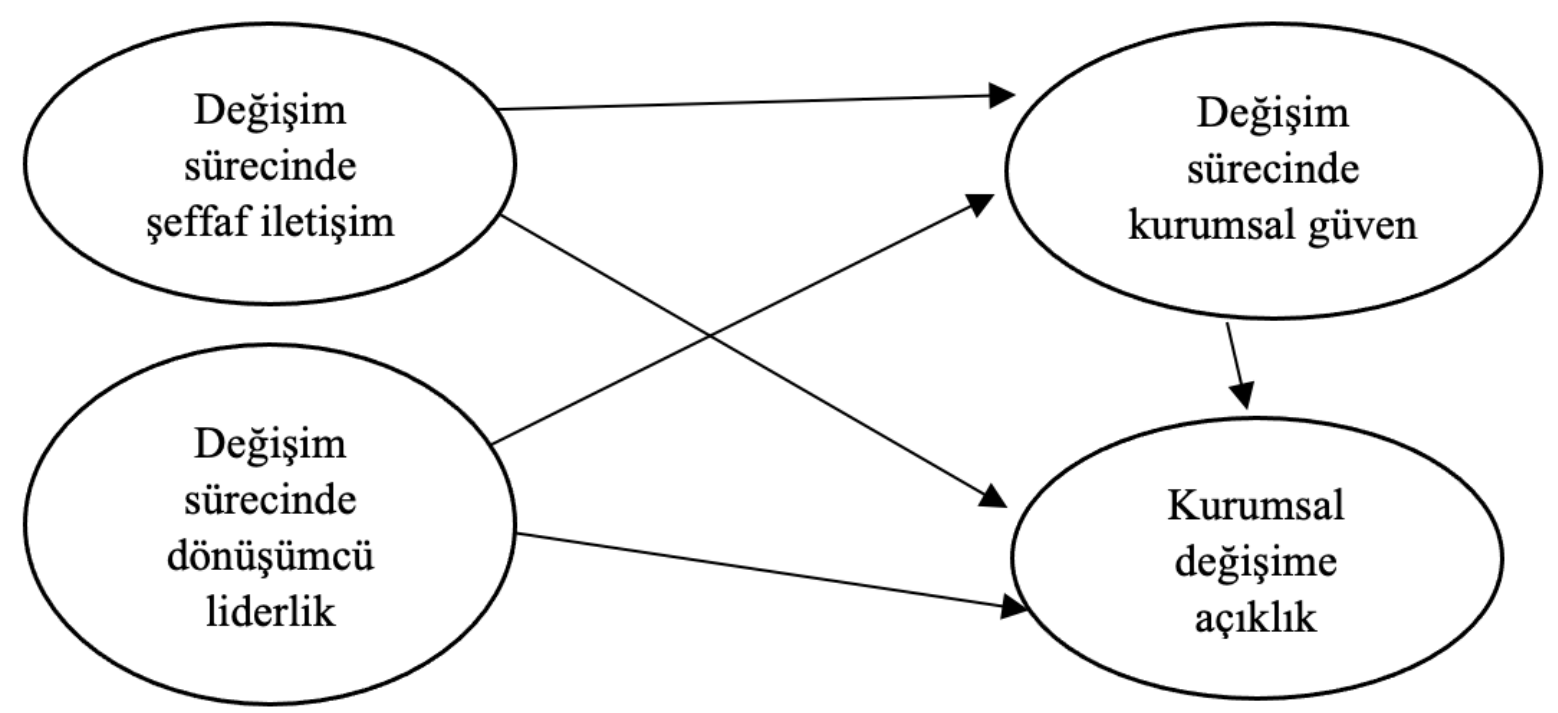

Şekil 1. Araştırmanın Modeli

Çalışmanın modeli ise Şekil 1'deki gibi oluşturulmuştur. Şekil 1'de, değişim sürecinde hem şeffaf iletişimin hem de dönüşümcü liderliğin kurumsal güven ve buna bağlı olarak kurumsal değişim ile doğrudan ilişkili olduğu bir model ifade edilmiştir.

\section{Araştırmanın Hipotezleri}

Araştırmanın amacı ve modeli doğrultusunda aşağıdaki hipotezler oluşturulmuştur:

H1: Değişim sürecinde şeffaf iletişim ile çalışanların kurumsal güvenleri arasında olumlu ilişki vardır.

H2: Değişim sürecinde şeffaf iletişim ile çalışanların değişime açık olması arasında olumlu ilișki vardır.

H3: Değișim sürecindeki dönüşümcü liderlik ile çalıșanların kurumsal güvenleri arasında olumlu ilişki vardır.

H4: Değişim sürecindeki dönüşümcü liderlik ile çalışanların değişime açık olmaları arasında olumlu ilişki vardır.

H5: Değişim sürecinde çalışanların kurumsal güveni ile çalışanların değişime açık olması arasında olumlu ilişki vardır.

\section{Etik Kurul İzni}

İstanbul Aydın Üniversitesi Sosyal Bilimler Etik Komisyonu 31/08/2020 tarih ve 2020/7 numaralı toplantısında alınan karar çerçevesinde çalışma etik açıdan bir sakınca içermemektedir. 


\section{Araştırma Verilerinin Analizi ve Bulgular}

Toplanan verilerin analizi SPSS 25 ve LISREL programları ile yapılmıştır. Güvenilirlik analizleri Cronbach Alpha güvenirlik katsayısı kullanılarak yapılmış olup, geçerlilik için ise açıklayıcı ve doğrulayıcı faktör analizleri yapılmıştır. Ankette yer alan önermelerin değerlendirilmesi, 5'li Likert ölçeğinde yapılmıştır. Hipotez testleri ile birlikte betimleyici istatistikler kullanılarak değişkenler tanımlanmıștır.

Yue, Men ve Ferguson (2019)'un yapmış oldukları çalışmanın güvenirlik oranları şeffaf iletişim için $\alpha=.92,5$ dönüşümcü liderlik için $\alpha=.84$, değişime açıklık için $\alpha=.87$ ve kurumsal güven için $\alpha=.92$ olarak oldukça yüksek oranlardadır. Bu çalışmada kullanılan ölçeklerden Şeffaf İletişim Ölçeği'nin Cronbach's Alpha değeri 0,994; Dönüşümcü Liderlik Ölçeği'nin Cronbach's Alpha değeri 0,941; Kurumsal Güven Ölçeği'nin Cronbach's Alpha değeri 0,910 ve Değișime Açlklık Ölçeği'nin Cronbach's Alpha değeri 0,740 olarak bulunmuştur. Bu değerler kullanılan ölçeklerin güvenilirliğinin oldukça yüksek olduğunu göstermektedir. Türkçeye ilk kez uyarlanarak hazırlanan bu ölçek için bu veriler önemli göstergelerdir.

Alfa katsayısının bulunabileceği aralıklar ve buna bağlı olarak da ölçeğin güvenirlik durumu şu şekilde verilmiştir: $0 \leq \alpha<0,40$ ise ölçek güvenilir değildir, $0,40 \leq \alpha<0,60$ ise ölçek düşük güvenilirliktedir, $0,60 \leq \alpha<0,80$ ise ölçek oldukça güvenilirdir, $0,80 \leq \alpha<$ 1 ise ölçek yüksek derecede güvenilir bir ölçektir. Buna göre, tüm alt boyutların güvenilir olduğu görülmüştür (Özdamar, 2004, s. 633).

Analiz sonucunda elde edilen uyum iyiliği değerleri aşağıda yer almaktadır.

Chi-Square $/ \mathrm{df}=2,97$

Estimated Non-centrality Parameter $(\mathrm{NCP})=2550.3$

90 Percent Confidence Interval for NCP $=(2378.00 ; 2730.09)$

Population Discrepancy Function Value (F0) $=6.04$

90 Percent Confidence Interval for F0 $=(5.64 ; 6.47)$

Root Mean Square Error of Approximation (RMSEA) $=0.098$

90 Percent Confidence Interval for RMSEA $=(0.095 ; 0.10)$

Expected Cross-Validation Index (ECVI) $=7.90$

90 Percent Confidence Interval for ECVI $=(7.49 ; 8.32)$

Normed Fit Index (NFI) $=0.96$

Non-Normed Fit Index $(\mathrm{NNFI})=0.96$

Parsimony Normed Fit Index (PNFI) $=0.89$

Comparative Fit Index (CFI) $=0.97$

Incremental Fit Index (IFI) $=0.97$

Relative Fit Index (RFI) $=0.95$

Standardized RMR $=0.059$

Goodness of Fit Index (GFI) $=0.90$

Tüm değerler kabul sınırları (Erkorkmaz, Etikan, Demir, \& Özdamar, 2013) içinde olup ölçeğin geçerli olduğu görülmüştür. Alt boyutlarda yer alan boyutların uygun sinırlar arasında olduğundan ölçeğin geçerli olduğu görülmüştür. $\mathrm{Bu}$ veriler de bu ölçeği kullanarak yapılan araştırmanın doğruluğunu ortaya koymaktadır.

Araștırmada kullanılan ölçeğin geçerliliğini araştırmak için ise LISREL programı ile bir doğrulayıcı faktör analizi (Tablo 1) yapılmıştır. 
Tablo 1. Ölçek Geçerlilik Çalışması (Doğrulayıcı Faktör Analizi / s:şeffaf iletişim, d:dönüşümcü liderlik, g: kurumsal güven, a:değişime açıklık)

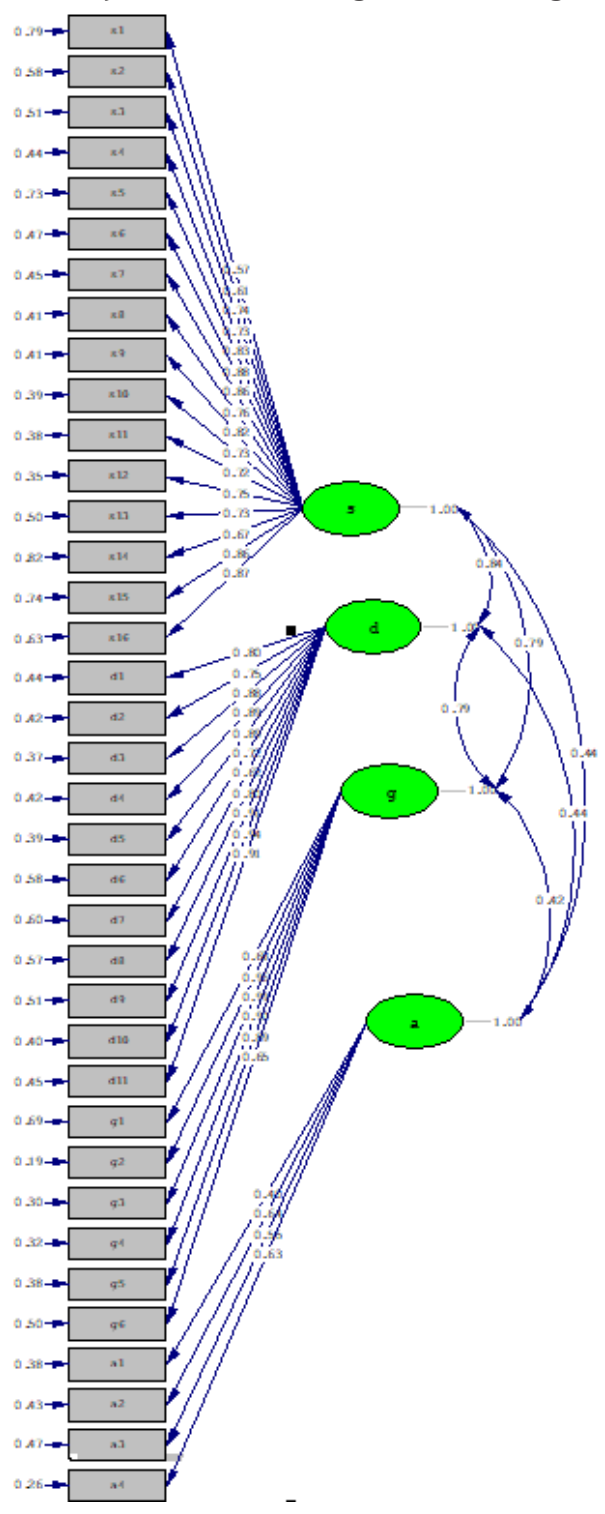

Araștırmaya katılanların 265'i (\%62,6) kadın ve 202'si (\%47,8) 35-49 yaş arasındadır. Katılımcıların 214'ü $(\% 50,6)$ bulundukları işte 11 yıldan fazla çalışmakta, 206'sı $(\% 48,7)$ üniversite mezunu ve 332'si $(\% 78,5)$ özel kurumda çalışmaktadır (Tablo 2).

Tablo 2. Katılımcıların Tanıtıcı Özellikleri

\begin{tabular}{|l|l|c|c|}
\hline \multicolumn{2}{|l|}{ Değişkenler (n=423) } & $\mathbf{n}$ & \% \\
\hline \multirow{4}{*}{ Cinsiyet } & Kadın & 265 & 62,6 \\
\cline { 2 - 4 } & Erkek & 158 & 37,4 \\
\hline \multirow{4}{*}{ Yaş } & $18-24$ & 45 & 10,6 \\
\cline { 2 - 4 } & $25-34$ & 128 & 30,3 \\
\cline { 2 - 4 } & $35-49$ & 202 & 47,8 \\
\hline \multirow{4}{*}{ Kıdem Durumu } & $50-64$ & 48 & 11,3 \\
\hline & 1 yıldan az & 40 & 9,5 \\
\cline { 2 - 4 } & $2-5$ yıl arası & 84 & 19,9 \\
\cline { 2 - 4 } & $6-10$ yıl arası & 85 & 20,1 \\
\cline { 2 - 4 } & 11 yıldan fazla & 214 & 50,6 \\
\hline
\end{tabular}




\begin{tabular}{|l|l|c|c|}
\hline \multicolumn{2}{|l|}{ Değişkenler (n=423) } & n & $\%$ \\
\hline \multirow{4}{*}{ Eğitim Durumu } & Lise & 33 & 7,8 \\
\cline { 2 - 4 } & Yüksekokul & 31 & 7,3 \\
\cline { 2 - 4 } & Üniversite & 206 & 48,7 \\
\cline { 2 - 4 } & Lisansüstü & 153 & 36,2 \\
\hline \multirow{2}{*}{ Kurum Türü } & Özel Kurum & 332 & 78,5 \\
\cline { 2 - 4 } & Kamu Kurumu & 91 & 21,5 \\
\hline
\end{tabular}

Araştırmada katılımcıların Şeffaf İletişim Ölçeğinden aldıkları toplam puan ortalamaları 52,96 \pm 12,47, Dönüșümcü Liderlik 36,83 \pm 9,39, Kurumsal Güven 18,87 \pm 5,30 ve Değişime Açıllık 14,67 £ 2,54 olarak bulunmuştur (Tablo 3).

Tablo 3. Şeffaf İletişim, Dönüşümcü Liderlik, Kurumsal Güven ve Değişime Açıklık Ölçekleri Puan Ortalamaları

\begin{tabular}{|l|c|c|c|}
\hline Ölçek Altboyutları $(\mathbf{n = 4 2 3 )}$ & Ort \pm SS & Medyan & Min-Max \\
\hline Şeffaf İletişim & $52,96 \pm 12,47$ & 55 & $17-80$ \\
\hline Dönüşümcü Liderlik & $36,83 \pm 9,39$ & 38 & $11-55$ \\
\hline Kurumsal Güven & $18,87 \pm 5,30$ & 19 & $6-30$ \\
\hline Değişime Açıklık & $14,67 \pm 2,54$ & 15 & $4-20$ \\
\hline
\end{tabular}

Araștırmada şeffaf iletişim ile çalışanların kurumsal güvenleri arasında \%74,6'lık pozitif korelasyon bulunmuştur. Korelasyon katsayısı anlamlıdır $(p=0,000<0,05)$, H1 kabul edilmiştir. Katılımcıların şeffaf iletişim puanları arttıkça kurumsal güven düzeyleri de artmaktadır.

Araştırmada şeffaf iletişim ile çalışanların değişime açı olması arasında \%38,2'lik pozitif korelasyon bulunmuştur. Korelasyon katsayısı anlamlıdır $(p=0,000<0,05)$, H2 kabul edilmiştir. Katılımcıların şeffaf iletişim puanları arttıkça kurumsal güven düzeyleri de artmaktadır.

Araştırmada dönüşümcü liderlik ile çalışanların kurumsal güvenleri arasında \%74,2'lik pozitif korelasyon bulunmuştur. Korelasyon katsayısı anlamlıdır $(p=0,000<0,05)$, H3 kabul edilmiştir. Katılımcıların şeffaf iletişim puanları arttıkça kurumsal güven düzeyleri de artmaktadır.

Araștırmada dönüşümcü liderlik ile çalıșanların değișime açık olmaları arasında \%38,4'lük pozitif korelasyon bulunmuştur. Korelasyon katsayısı anlamlıdır $(p=0,000<0,05)$, H4 kabul edilmiştir. Katılımcıların şeffaf iletişim puanları arttıkça kurumsal güven düzeyleri de artmaktadır.

Araștırmada çalıșanların kurumsal güveni ile değişime açık olması arasında \%35,1'lik pozitif korelasyon bulunmuştur. Korelasyon katsayısı anlamlıdır $(p=0,000<0,05)$, H5 kabul edilmiştir. Katılımcıların şeffaf iletişim puanları arttıkça kurumsal güven düzeyleri de artmaktadır (Tablo 4).

Tablo 4. Şeffaf İletişim, Dönüşümcü Liderlik, Kurumsal Güven ve Değişime Açıklık Puan Ortalamaları Arasındaki İliş̧ki

\begin{tabular}{|l|l|c|c|c|}
\hline \multicolumn{2}{|l|}{} & Şeffaf İletişim & Dönüşümcü Liderlik & Kurumsal Güven \\
\hline \multirow{2}{*}{ Değişime Açıklık } & $\mathrm{r}$ & 0,382 & 0,384 & 0,351 \\
\cline { 2 - 5 } & $\mathrm{p}$ & 0,000 & 0,000 & 0,000 \\
\hline \multirow{2}{*}{ Kurumsal Güven } & $\mathrm{r}$ & 0,746 & 0,742 & \\
\cline { 2 - 5 } & $\mathrm{p}$ & 0,000 & 0,000 & \\
\hline
\end{tabular}


Veriler ve bulgular tüm hipotezlerin kabul edildiğini ortaya koymaktadır. $\mathrm{Bu}$ da şeffaf iletişimin ve dönüşümcü liderliğin değişim esnasında çalışanların güvenini ve değişime uyum sağlamalarını doğrudan etkilediğini göstermektedir.

\section{Sonuç ve Değerlendirme}

Kurumsal ve bireysel değişimin önüne geçilemez olduğu bir yüzyılda yaşıyoruz. Teknolojik yenilikler, rekabet, müşteri talepleri, ulusal-uluslararası krizler, küreselleşme, siyasi, ekonomik ve sosyo-kültürel olaylar sürekli bir değişimi körüklemektedir. Kurumsal değişimin başlatılması ve yürütülmesindeki baş aktörler ise liderlerdir. Kurumsal değişimlerin başarıya ulaşmasında 21. yüzyılın liderlik anlayışı çerçevesinde karizmatik, güdüleyici, entelektüel, vizyoner, empati sahibi, yenilikçi özellikleri ile dönüşümcü liderler öne çıkmaktadır. Ancak değişimin başarıya ulaşması liderlerin iletişimi nasıl ve ne biçimde kullandıkları ile de yakından ilgilidir.

Bir yönetim fonksiyonu olarak halkla ilişkiler de kurumun her önemli politikasında olduğu gibi stratejik rolünü ön plana çlkararak her türlü değişim projesini yönetmek ve yönlendirmekle yükümlüdür. Birçok fonksiyonu bünyesinde barındıran halkla ilişkiler, değişim gibi kaotik ve kriz ortamlarında kurum içi ve kurum dışı sağlıklı bilgi akışının sağlanmasında önemli bir göreve sahiptir. Ani ya da planll, her ne boyutta olursa olsun bir bilinmezlik içeren değişim sürecinde çalışanların değişime adaptasyonu ve kurumlarına karşı olan güvenlerinin sağlanması hem yöneticilerin hem de kurumda sağlanacak şeffaf iletişimin etkinliği daha önce yapılan araștırmalarda olduğu gibi göz ardı edilemez bir gerçektir.

Değișim yönetimi ve onu yöneten dönüşümcü liderlik literatürde genelde işletme bakış açısıyla ele alınırken bu çalışmada halkla ilişkiler perspektifiyle farklı yönden ele alınmaktadır. Bu çalışmada özellikle değişim aşamasında olan kurumlar arasında bir inceleme yapılması düşünülürken, araştırmanın Covid-19 pandemi sürecine denk gelmesi ve hem kişisel hem de kurumsal anlamda herkesi bir değişim sürecine sokması nedeniyle ayrım yapmaksızın tüm kurumlar bu kapsamda ele alınmıştır. İstanbul il sınırları içinde özel ve kamu kurum çalışanları arasında yapılan araştırmada ankete cevap veren 423 kişinin değişim sürecinde dönüşümcü liderlik, şeffaf iletişim konusundaki değerlendirmeleri incelenmiştir.

Etkili iletişimin kurumsal değişim literatüründe önemli fakat az gelişmiş bir kavram olduğunu kabul eden Johansson ve Heide (2008), yaptıkları akademik taramada kurumsal değişimle ilgili çok sayıda çalışma olmasına rağmen iletişim yaklaşımının çok az ele alındığını belirtirken; Yue, Men ve Ferguson (2019)'un araştırması ve Türkiye'de yapılan bu araștırma başarılı değișim yönetiminde şeffaf iletişimin önemi hakkında ek kanıtlar sunmaktadır. Temel olarak bu alanda ve bu kapsamda yapılan ilk çalışma olan Yue, Men ve Ferguson (2019)'un bulguları dönüşümcü liderlik ile çalışanların kurumsal güveni arasında olumlu ve anlamlı bir ilişki olduğunu, dönüşümcü liderliğin çalışanların örgütsel güvenini sağlamada olumlu bir rol oynadığını göstermiştir. Bu çalıșma da Yue, Men ve Ferguson (2019)'un araştırma sonuçlarını destekler nitelikte olup dönüşümcü liderlik ile çalışanların kurumsal güvenleri arasında pozitif korelasyon bulunmuştur.

Bu sonuç şunu ifade etmektedir; değişim vizyonunu etkili bir şekilde ileten, çalışanlarına kişisel bazda ilgi gösteren, çalışanlarına ilham veren, dönüşümcü liderler çalışanların kurumsal güvenini artırmaktadır. 
Yue, Men ve Ferguson (2019) hem dönüşümcü liderlik hem de şeffaf iletişim ve çalışanların değişime açıklığı arasında doğrudan pozitif bir ilişki bulamamışlardır. Ancak yapılan bu araştırmada dönüşümcü liderlik ile çalışanların değişime açı olmaları arasında ve şeffaf iletişim ile çalışanların değişime açık olması arasında pozitif korelasyon bulunmuştur. Yue, Men ve Ferguson (2019) şeffaf iletişimin çalışanların kurumsal güvenini ve çalışanların değişime açıklığını geliştirmeye olumlu etkisi olduğunu ortaya koymaktadırlar. Bu çalışmada da şeffaf iletişim ile çalışanların kurumsal güvenleri arasında pozitif korelasyon bulunmuştur.

Katılımcıların kurum içi artan şeffaf iletişim sayesinde kurumlarına daha yüksek oranda güven duydukları görülmektedir. Çünkü değişim gibi kaotik durumlarda açık, sürekli ve net iletişim kurulması söylentileri, dezenformasyonu ortadan kaldıracağı için çalışanların güvenini artırma oranı da yüksek olacaktır. Bu sonuç katılımcılık, hesap verebilirlik, önemlilik ayaklarından oluşan şeffaf iletişimin değişim sırasında güven geliştirilmesinde anahtar rol oynadığını göstermektedir. Pitt, Murgolo-Poore ve Dix (2001)'te etkili iletişimin, değişim yönetiminin başarısında kilit rol üstendiğini ifade etmişlerdir.

Yue, Men ve Ferguson (2019) şeffaf iletişimin ve dönüşümcü liderliğin kurumsal güven yoluyla değişime açık olmada önemli ama dolaylı etkisi olduğunu göstermiştir. Yapılan bu çalışmada da çalışanların kurumsal güveni ile değişime açı olmaları arasında pozitif korelasyon bulunmuştur. Bu da kurumlarına güven duyan çalışanların kurumlarının istediği değişime daha çabuk uyum sağladıklarını göstermektedir.

Benzer şekilde Men ve Stacks (2014) şeffaf iç iletişimin çalışan güveni, kurumsal itibar ve çalışan-organizasyon ilişkilerini geliştirmede yapıcı olduğunu ortaya koymuştur. Bu çalışmanın sonuçları da şeffaf iletişimin çalışanlarla kaliteli ve sağlıklı bir ilişki kurmada kritik bir rol oynadığını göstermiştir. Değişim sürecinde şeffaf iletişim kurarak çalışanları ile bilgi paylaşımı yapan, katılımcılığı destekleyen kuruluşların çalışanların güvenini kazanma olasılığının yüksek olduğu bu çalışma ile bir kere daha gösterilmiştir. Şöyle ki kurulan açık, dürüst ve etik iletişim, çalışanlar ve kurum arasındaki bilgi boşluğunu kapatıp bu süreçle ilgili yanlış ve söylenti bilgileri azaltacağı için çalışanların kaygı ve stresini de azaltabilir.

Kurum içi halkla ilişkiler perspektifinden bakıldığında, Men ve Stacks'ın (2014) araștırması da liderliğin örgütün simetrik ve şeffaf iletişimini etkileyerek hem doğrudan hem de dolaylı olarak örgüt-çalışan ilişkisini olumlu etkilediğini göstermiştir. Rawlins (2008) de şeffaf iç iletişim ile çalışanların kurumsal güvenleri arasında olumlu bir ilişki olduğunu, şeffaf iletişim sayesinde çalışanların güveninin güçlendirilebileceğini tespit etmiştir.

Braun, Peus, Weisweiler ve Frey (2013) dönüşümcü liderliğin, çalışanların olumlu tutumlarını desteklediğini, güven ve kurumsal memnuniyeti geliștirmeyi tetiklediğini bulmuşlardır. Wang, Oh, Courtright ve Colbert (2011) de kurumsal değişim sırasında, liderlerin çalışanlara duygusal destek verdiklerini dolayısıyla çalışanların kuruluşa karşı güven gösterme eğiliminde olduklarını bulmuşlardır.

Gerek normal iş sürecinde gerekse değişim gibi kaotik dönemlerde çalışanların desteklenmesi, onlarla birlikte hareket edilmesi sadece o anlık işlerin yürümesini değil, uzun vadede çalışan güvenini, motivasyonu ve bağlılığını da etkileyen önemli bir ayrıntıdır. Thomas ve Velthouse (1990) maddi ve manevi desteklenen çalışanların daha yüksek konsantrasyon, inisiyatif ve dayanıklılık seviyelerine sahip olduklarını ve 
bunun da kurumsal bağlılık seviyelerini artırdığını öne sürmüștür. Başka bir deyişle, kurumlarından anlam ve değer duygusu elde eden çalışanların, kurumlarına daha fazla bağlılık göstermeleri muhtemel görünmektedir (Avolio, Zhu, Koh, \& Bhatia, 2004).

Bir kurumu yönetmek, yönetim politikalarını çizmek ve uygulamak en stratejik pozisyon olan liderlerin görevidir. Liderlerin davranışları sadece kurumu değil çalışanların da tutum ve davranışlarını doğrudan etkilemektedir. Liderler, vaatlerini yerine getirdiklerinde, çalışanlarına karşı şeffaf ve açık olduklarında çalışanlarının daha çok güvenini kazandığından değişim gibi önemli süreçlerde daha büyük başarı getirmektedir. Değişim sırasında özellikle de dönüşümcü liderlerin göstereceği duygusal bağ, esneklik, anlayış belirsizlik içindeki çalışanların kendilerini daha güçlü ve desteklenmiş hissetmelerini sağlar ki bu da çalışanların kurumlarına bağlılıklarını teşvik eder. Sadece dönüşümcü liderler değil şeffaf iletişim yöntem ve araçları da çalışanların değişime karşı olumlu tutum, davranış ve güven yaratımında pozitif etkiye sahiptir. Men ve Stacks'ın (2014) araştırmaları da şeffaf iç iletişimin çalışan güveni, kurumsal itibar ve çalışankurum ilişkilerini geliştirmede yapıcı olduğunu ortaya koymaktadır.

Kurumun lideri ve iletişim yöneticilerinin iyi niyetli ve samimi yaklaşımı güven oluşumunu desteklerken, çalışanların değişeme karşı algı ve vizyonlarını etkileme ve dolayısıyla onlara bu süreci sahiplenme gücü de vermektedir. Bu çalışma da şeffaf iletişim, çalışan güveni ve değişime tepki arasındaki doğrudan bağlantıyı vurgulayarak araştırma boşluğunu doldurmuştur. Ayrıca değişim esnasında güven ortamının yaratılması gerekliliği konusunda da istatistiki bulgular sunmaktadır.

Teorik olarak bu çalışma bilginin, katılım ve hesap verebilirliğinin önemli olduğu şeffaf iletişim ve iç halkla iliş̧iler perspektifinden değişime katkıda bulunurken; değişim sırasındaki güven ve değişime açıklık üzerindeki etkisiyle de iletişim literatürüne katkı sunmaktadır. Çalışma ayrıca dönüşümcü liderliğin değişim yönetimi esnasında iletişimin unsurlarıyla nasıl etkileşime girdiğini göstermektedir.

Nasıl günümüz dijital bilgi ve iletişim teknolojileri kullanıcılarına esnek, katılımcı, şeffaf, erişilebilir ortamlar sunuyorsa, bireyler de iş dünyasından benzer bir iletişim atmosferi beklemektedir. Dolayısıyla kurum ve halkla ilişkiler liderleri etkin ve verimli yönetim çerçevesinde iletişim politikalarında șeffaflığa doğru bir değișimi savunmalıdırlar. Çalışanlar değişimin nedeni, gereklilikleri, nasıl yapılacağı, olası sonuçları konusunda aralıklarla bilgilendirilmelidir. Şeffaflık çerçevesinde kurumlar simetrik davranış sergileme konusunda kendilerini geliştirmelidir. Bu çalışma da başarılı değişim sürecinde liderlerin ve şeffaf iletişimin kritik öneme sahip olduğunu, bu alanda çalışmaların güçlendirilmesi gerektiğini ortaya koymuştur.

Türkçe literatür açısından ele alındığında bu kapsam ve içerikte bir çalışma bir ilki oluşturmaktadır. Bu açıdan değerlendirildiğinde hazırlanan çalışma, mevcut literatürdeki boşluğu doldurması açısından önem arz etmektedir. Bu çalışma bir ön araştırma olup, bu tür diğer araştırmalar için yol gösterici niteliktedir. Bu nedenle yapılacak diğer çalışmalar; farklı iller, sektörler, hedef kitleler vb. nezdinde daha kapsamlı biçimde yeni çalışmalarla desteklenmesinde yarar bulunmaktadır.

\section{Çalışmanın Etik İzin Bilgileri}

İstanbul Aydın Üniversitesi Sosyal Bilimler Etik Komisyonu 31/08/2020 tarih ve 2020/7 nolu toplantısında alınan karar çerçevesinde çalışma etik açıdan bir sakınca içermemektedir. 


\section{Kaynakça}

Abdul Rashid, Z., Sambasivan, M., \& Abdul Rahman, A. (2004). The influence of organizational culture on attitudes toward organizational change. Leadership \& Organization Development Journal, 25(2), s. 161-179. doi:https://doi. org/10.1108/01437730410521831.

Aksaraylı, M. (2015). Dönüștürücü liderlik ve değişimde dönüştürücü liderlik paradigması. Süleyman Demirel Üniversitesi Vizyoner Dergisi, 6(12), s. 108-124. https://dergipark.org.tr/tr/pub/vizyoner/issue/23004/246021 adresinden alınd 1

Al-Qura'an, A. (2016). The impact of transformational leadership on organizational change management: case study at jordan ahli bank. IOSR Journal of Business and Management (IOSR-JBM), 17(12), s. 1-7. doi: 10.9790/487X-171210107

Alvesson, M., \& Sveningsson, S. (2016). Changing organizational culture: cultural change work in progress. Newyork: USA: Routledge.

American Management Association. (2019). What's changed in change management. Newyork: American Management Association.

Appelbaum, S., Degbe, M., MacDonald, O., \& Nguyen-Quang, T. (2015). Organizational outcomes of leadership style and resistance to change. Industrial and Commercial Training, 47(3), s. 135-144. doi:https://doi.org/10.1108/ICT-07-2013-0045

Augustsson, H., Richter, A., Hasson, H., \& von Thiele Schwarz, U. (2017). The need for dual openness to change: A longitudinal study evaluating the impact of employees' openness to organizational change content and process on intervention outcomes. The Journal of Applied Behavioral Science, 53(3), s. 349-368. doi:https:// doi. org/10.1177/0021886317691930.

Avolio, B., Zhu, W., Koh, W., \& Bhatia, P. (2004). Transformational leadership and organizational commitment: Mediating role of psychological empowerment and moderating role of structural distance. Journal of Organizational Behavior, 25(8), s. 951-968.

Bartlett, C., \& Ghoshal, S. (1995, Fall). Rebuilding behavioral context: turn process reengineering into people rejuvenation. Sloan Management Review, s. 11-23.

Bass, B. (1985). Leadership and performance beyond expectations. New York: Free Press.

Bass, B. (1995). Theory of transformational leadershıp redux. Leadership Quarterly, 6(4), s. 463-478. doi:https://doi.org/10.1016/1048-9843(95)90021-7.

Bass, B., \& Avolio, B. (2004). Multifactor leadership questionnaire manual (3 b.). Menlo Park CA: Mind Garden Inc.

Baykal, E. (2019). A human factor in change management: an example from turkish banking sector. Balkan Sosyal Bilimler Dergisi,, 8(16), s. 187-198.

Beck, N., Brüderl, J., \& Woywode, M. (2008). Momentum or deceleration? theoretical and methodological reflections on the analysis of organizational change. Academy of Management Journal, 51(3), s. 413-435. doi:https://doi.org/10.5465/ AMJ.2008.32625943. 
Bouckenooghe, D., Devos, G., \& Van Den Broeck, H. (2009). Organizational change questionnaire-Climate of change, processes and readiness: Development of a new instrument. The Journal of Psychology, 143(6), s. 559-599. doi:10.1080/00223980903218216

Braun, S., Peus, C., Weisweiler , S., \& Frey, D. (2013). Transformational leadership, jobsatisfaction, and team performance: A multi level mediation model of trust. The Leadership Quarterly, 24(1), s. 270-283. doi:https://doi.org/10.1016/j. leaqua.2012.11.006

Brown, S., \& Eisenhardt, K. (1997, March). The art of continuous change: linking complexity theory and time-paced evolution in relentlessly shifting organizations . Administrative Science Quarterly, 42(1), s. 1-34.

Burns, J. (1978). Leadership. New York: USA: Harper \& Row.

Cai, W., Loon, M., \& Wong, P. (2018). Leadership, trust in management and acceptance of change in Hong Kong's Civil Service Bureau. Journal of Organizational Change Management, 31(5), s. 1054-1070. doi:https://doi.org/10.1108/JOCM-10-20160215

Cook, K., Yamagishi, T., Cheshire, C., \& Mashima, R. (2005, June). Trust building via risk taking: a cross-societal experiment . Social Psychology Quarterly, 68(2), s. 121-142. doi:https://doi.org/10.1177/019027250506800202

Devos, G., Buelens, M., \& Bouckenooghe, D. (2007). Contribution of content, context, and process to understanding openness to organizationa lchange: Two experimental simulation studies. The Journal of Social Psychology, 147(6), s. 607-630.

Drucker, P. (2000). 21. yy İçin Yönetim Tartışmaları. (İ. Bahçıvangil, \& G. Gorbon, Çev.) İstanbul: Turkey: Epsilon.

Eisenbach, R., Watson, K., \& Pillai, R. (1999). Transformational leadership in the context of organizational change. Journal of Organizational Change Management, 12(2), s. 80-88. doi:dx.doi.org/10.1108/09534819910263631.

Erdoğan, Z., \& Hepkul, A. (2017). Genel işletme. Eskişehir: Turkey: Anadolu Üniversitesi Yayınları.

Erkorkmaz, Ü., Etikan, İ., Demir, O., \& Özdamar, K. (2013). Confirmatory factor analysis and fit indices: Review. Turkiye Klinikleri J Med Sci, 33(1), s. 210-223.

Grunig, J. (2005). Halkla ilişkiler ve iletişim yönetiminde mükemmellik. İstanbul: Turkey: Rota Yayınları.

Herold, D., Fedor, D., \& Caldwell, S. (2007). Beyond change management: A multilevel investigation of contextual and personal influences on employees' commitment to change. Journal of Applied Psychology, 92(4), s. 942-951.

House, R., Spangler, W., \& Woycke, J. (1991). Personality and charisma in the US presidency: a psychological theory of leadership effectiveness. Administrative Science Quarterly, 36(3), s. 364-395.

Johansson, C., \& Heide, M. (2008). Speaking of change: Three communication approaches instudies of organizational change. Corporate Communications: An International Journal, 13(3), s. 288-305. doi:https://doi.org/10.1108/13563280810893661.

Koçel, T. (2011). Işsletme yöneticiliği. İstanbul: Turkey: Beta Yayınları. 
Kouzes, J., \& Posner, B. (1993). The leadership challenge: how to make extraordinary things happen in organizations. San Francisco: USA: Jossey-Bass.

Manning, T. (2012). Managing change in hard times. Industrial and Commercial Training, 44(5), 259-267. (tarih yok). doi: 10.1108/00197851211244997.

Manning, T. (2012). Managing change in hard times. Industrial and Commercial Training, 44(5), s. 259-267. doi:10.1108/00197851211244997

Men, L., \& Stacks, D. (2014). The effects of authentic leadership on strategic internal communication and employee-organization relationships. Journal of Public Relations Research, 26(4).

Men, R., \& Bowen, S. (2017). Excellence in internal relations management. NewYork: USA: Business Expert Press.

Men, R., \& Yue, C. (2019). Creating a positive emotional culture: Effect of internal communication and impact on employee supportive behaviors. Public Relations Review, 45(3), s. 1-12. doi:10.1016/j.pubrev.2019.03.001

Miller, F. (1998, Summer). Strategic culture change: the door to achieving high performance and inclusion. Public Personnel Management, 27(2). doi:https://doi. org/10.1177/009102609802700203.

Moorehead, G., \& Griffin , R. (2010). Organizational behavior (9 b.). Texas: USA:A\&M University.

Nadler, D. (1983). Concepts for the management of organizational change. J. Hackman, E. Lawler, \& L. Porter içinde, Perspectives on Behavior in Organizations. NewYork: USA: McGraw Hill.

Özdamar, K. (2004). Paket programlar ile istatistiksel veri analizi. Eskișehir: Turkey: Kaan Kitabevi.

Özkalp , E., \& Kırel , Ç. (2010). Örgütsel davranış. Bursa: Turkey: Ekin Yayınevi.

Parry, K. (1998, Spring). Grounded theory and social process: a new direction for leadership research. Leadership Quarterly, 9(1), s. 85-105. doi:https://doi. org/10.1016/S1048-9843(98)90043-1

Paşa, M. (2002). Yaşam kalitesini yükselten temel unsur olarak işin insancıllaştırılması . İş, Güç, Endüstri İlişkileri ve Insan Kaynakları Dergisi, 4(1). http://www.isguc. org/?p=article\&id=280\&cilt=4\&sayi=1\&yil=2002. adresinden alınd 1

Pawar, B., \& Eastman, K. (1997). The nature and implications of contextual influences on transformational leadership: a conceptual examination. Academy of Management Review, 1(22), s. 80-109. doi:10.2307/259225.

Pitt, L., Murgolo-Poore, M., \& Dix, S. (2001). Changing change management: the intranet as catalyst. Journal of Change Management, 2(2), s. 106-114. doi:10.1080/714042496

Rawlins, B. (2008). Measuring the relationship between organizational transparency and employee trust. Public Relations Journal, 2(2), s. 1-21.

Robbins, S., Millett, B., \& Waters-Marsh, T. (2008). Organizational behavior. Australia:,Pearson Education. 
Saylı, H., \& Tüfekçi, A. (2008, Ocak-Haziran). Başarılı bir örgütsel değişimin gerçekleştirilmesinde dönüștürücü liderliğin rolü . Erciyes Üniversitesi İktisadi ve İdari Bilimler Fakültesi Dergisi(30), s. 193-210.

Seitel, F. (2016). Halkla iliş̧kiler uygulaması. (S. Çakar Mengü, Dü.) Ankara: Turkey: Nobel Akademik.

Selvi, S. (2007). Her değişim gelişim değildir: Öğrenen örgütlerin gelişim sürecinde psikolojinin yeri . Y. Ertürk (Dü.) içinde, Halkla İlişkiler Alanına Örgütsel Davranış Yansımaları . Ankara: Turkey: Nobel Yayın Dağıtım.

Simons, T. (1999). Behavioral integrity as a critical ingredient for transformational leadership. Journal of Organizational Change Management, 12(2), s. 89-104. doi:https://doi.org/10.1108/09534819910263640

Thomas, K., \& Velthouse, B. (1990). Cognitive elements of empowerment: an 'interpretive' model of intrinsic task motivation. (666-681, Dü.) Academy of Management Review, 15. doi:10.2307/258687

Van Knippenberg, D., \& van Leeuwen, E. (2001). Organizational identity after a merger: Sense on continuity as a key to postmerger identification. M. Hogg, \& D. Terry içinde, Social identity processes in organizational contexts (s. 249-264). Philadelphia: USA:Psychology Press.

Verčič, A., \& Vokić , N. (2017). Engaging employees through internal communication. Public Relations Review, 43(5), s. 885-993. doi:https://doi.org/10.1016/j. pubrev.2017.04.005

Wang, G., Oh, S., Courtright, S., \& Colbert, A. (2011). Transformational leadership and performance across criteria and levels: Ameta-analytic review of 25 years of research. Group \& Organization Management, 36(2), s. 223-270. doi:https://doi. org/10.1177/105

Wong, C., \& Cummings, G. (2009). The influence of authentic leadership behaviors on trust and work outcomes of health care staff . Journal of Leadership Studies, 3(2), s. 6-23. doi:https://doi.org/10.1002/jls.20104.

Yue, C., Men, L., \& Ferguson, M. (2019, September). Bridging transformational leadership, transparent communication, and employee openness to change: The mediating role of trust. Public Relations Review, 45(3), s. 1-13 . doi:https://doi. org/10.1016/j.pub

Yukl, G. (2018). Örgütlerde liderlik. Ankara: Turkey: Nobel Akademik Yayıncılık. 


\title{
The Role of Transparent Internal Communication and Transformational Leadership in Public Relations in Corporate Change and Corporate Trust Building
}

\author{
Gonca Yıldırım (Asst. Prof. Dr.)
}

\section{Extended Abstract}

The dimension of change - either sudden or planned, or proactive or reactive - does not matter; the change itself is a chaotic, indecisive, uncertain, and complicated process anyway. Change is a process that requires vision, motivation, support, collaboration. Therefore, the change management requires specifically the sense of transformational leadership among many other leadership forms of the 21st century, on the contrary of the leaders of the last century. While they were managing their institutions and the changes in them, leaders' most important weapon is communication. Likewise, in public relations -which is also a management function- the main issue is communication. However, most of the studies relating to change management were examined, and it is found out that they are mostly business-oriented and management-organization-oriented studies, and it is seen the perspective of public relations is overlooked.

The role of transparent communication and transformational leadership among workers in the constitution of institutional trust and the openness to change in the change process are examined in this study issued based on the observations above. The role of transformational leadership and transparent communication in the management of change and the constitution of institutional trust, are examined collectively for the first time within the scope of this study. For this reason, the main problem of this study is to evaluate the effects of transparent communication and transformational leadership in catalyzing the trust of employees and openness to change of employees.

The research was planned to be executed among specifically the institutions which are in a process of change in the very first stage of this study. However, as the research coincides with COVID-19 and it forces everybody both personally and institutionally to change, this limitation on the institutions has been removed. Therefore, all the institutions were examined without distinction in that context. The research base of the study is based on survey data among 423 people were obtained through the simple random sample method. The scale used by Yue, Men \& Ferguson (2019) in their articles "Bridging transformational leadership, transparent communication, and employee openness to change: The mediating role of trust", is adapted to Turkish and Turkey in this research. Ethically, permission was obtained from Yue et al. before the usage of scale.

Johansson and Heide (2008), in their academic surveillance, stress that even though there are variably study concerned institutional change, communication approaches were ignored. In this regard, this study is held in Turkey and the research of Yue, Men, \& Ferguson, (2019) in America introduces significant findings regarding the importance of leaders and transparent communication in productive and successful change management. The results of Yue, Men, \& Ferguson, (2019), which are the first studies held in this field, and this study consistent with each other; and there is a positive correlation has found between transformational leadership and the institutional trust of employees. On the contrary of Yue et al., a direct positive relation has found out between 
both transformational leadership, and transparent communication, and the openness of employees to change in this study.

Many other various studies in this scope are such as to corroborate these. For instance, Pitt, Murgolo-Poore \& Dix (2001) argue that effective communication has got a key role in the success of change management; Men \& Stacks (2014) argues transparent internal communication is a constructive factor in the improvement of employee-institution, institutional reputation and trust of the employee; Rawlins (2008) claims that there is a positive relation between transparent inner communication and institutional trust of employees, and it strengthened the trust of employees. Braun, Peus, Weisweiler \& Frey (2013) suggests that transformational leadership improves the trust and positive emotions of employees; Wang, Oh, Courtright \& Colbert, (2011) suggest that any emotional supports showed by leaders to their employees, affects the trust of employees positively.

These findings show us that the institutional trust of employees is developed by the transformational leaders who fairly explain the change process, show intimacy, and give inspiration to employees. In addition to that, symmetrical and transparent communication itself also ensures this process to be more reliable by clearing away all the rumors and erroneous information during the change process which is a chaotic and indecisive period. Transparent communication with its participation, consider and accountability features, plays a key role for employees to have trust in their institutions and leaders. It seems that employees who have got a feeling of trust, are most probable to embrace the change and the services they have done in the change, and adapting the change.

This study, which is pre-study and significant regard to filling the gap in existing scope, is a guiding study for other researches that will be made with other paradigms.

Keywords: Public Relations, Transparent Communication, Transformational Leadership, Corporate Change, Corporate Trust.

Bu makale intihal tespit yazılımlarıyla taranmıştır. İntihal tespit edilmemiştir.

This article has been scanned by plagiarism detection softwares. No plagiarism detected.

Bu çalışmada "Yükseköğretim Kurumları Bilimsel Araştırma ve Yayın Etiği Yönergesi” kapsamında uyulması belirtilen kurallara uyulmuştur.

In this study, the rules stated in the "Higher Education Institutions Scientific Research and Publication Ethics Directive" were followed. 